Коваль С. І., ст. викладач (Національний університет водного господарства та природокористування, м. Рівне)

\title{
ОСОБЛИВОСТІ ФОРМУВАННЯ ІНТЕГРОВАНИХ МАРКЕТИНГОВИХ КОМУНІКАЦІЙ В УМОВАХ КОНКУРЕНТНОГО СЕРЕДОВИЩА
}

В умовах глобалізації економіки, розширення конкурентного середовища все більше зростає роль інформації, вона стає одним із найбільш значимих елементів, що використовуються для ефективного управління діяльністю суб'єктів господарювання. Зростаючі темпи інформатизації суспільства надають споживачам все більші обсяги інформації. її передача від об'єкта до об'єкта відбувається за допомогою специфічної форми спілкування - комунікацій. У вирішенні цих завдань основне місце належить інтегрованим маркетинговим комунікаціям. Однак нестабільна економічна ситуація в країні, труднощі з фінансуванням відповідних заходів привели до скорочення маркетингових бюджетів. Тому зростає необхідність пошуку економічних і одночасно ефективних способів комунікації зі споживачами. Тільки ті компанії, які добре знають і розуміють своїх споживачів (клієнтів) і конкурентів, проводять ефективну комунікаційну політику, будуть мати успіх на цільовому ринку.

Ключові слова: маркетингові комунікації, інтегровані комунікації, споживачі, інформація, обмін.

Постановка проблеми. В умовах посилення конкурентного тиску зростає значимість нецінових факторів конкуренції, все більше уваги приділяється розробці ефективної комунікативної політики, використовуючи всі види комунікаційного інструментарію в маркетинговій діяльності. При будь-якому наборі елементів комунікацій необхідно застосовувати інтегрований підхід, тобто єдиний комплекс, направлений на цільові групи споживачів. Інтегрованість маркетингових комунікацій передбачає комплексне використання всіх елементів - реклами в засобах масової інформації, особистих продажів, стимулювання збуту, які дають найбільший ефект від їх спільного використання. Зберігаючи цілісне позиціонування в рамках кожного цільового сегменту, інструменти комунікації підсилюють один одного, створюючи синергічний ефект, який є результатом централізованої, чітко сформульованої і послідовно здійснюваної стратегії інтеграції маркетингових комунікацій.

Аналіз останніх досліджень та публікацій. Дослідженням про- 
Серія «Економічні науки»

Випуск 4(84) 2018 р.

блем у сфері маркетингових комунікацій, в тому числі інтегрованих, займались такі вчені, як: Р. Бартра, С. Божук, Л. Ковалик, Котлер Ф., Ж. Ламбен, Р. Лаутерборн, А. Панько, П. Смит, М. Стариков, Д. Шульц.

Метою статті $є$ дослідження теоретико-методологічних аспектів інтегрованої системи маркетингових комунікацій та визначення особливостей їх формування в умовах конкурентного середовища.

Викладення основного матеріалу. У широкому розумінні під маркетинговими комунікаціями необхідно розуміти всю сукупність інформаційних сигналів, які активно чи пасивно передають і приймають основні суб'єкти ринку.

Комунікація взагалі - це постійна активність. Це універсальна і одна із основних характеристик як людського спілкування, так і діяльності будь-яких організацій. Сфера їі застосування настільки ж широка, як і саме суспільство, яке нею користується, адже без комунікації не відбувається ні один акт соціально-економічної взаємодії. Базовими характеристиками комунікації $є$ відправлення і отримання знань, ідей, фактів, образів, цілей, емоцій та цінностей [6]. Комунікації $є$ центральною ланкою спілкування людей один із одним, забезпечуючи узгодженість їхніх дій; вона $є$ важливим елементом всіх міжособистісних зв'язків, з яких і виникає життя суспільства в цілому.

У формуванні потоків внутрішньої інформації зацікавлені, перш за все, маркетологи. Типові комунікаційні задачі маркетологів обмежуються комунікаційними наборами, під якими розуміється певна комбінація комунікаційних інструментів, призначених для доставки певної інформації різної вагомості цільовій аудиторії в рамках виділеного бюджету.

Комунікаційні процеси мають велике значення в спілкуванні людей і розвитку суспільства в цілому, а також входять в число найбільш актуальних проблем людства. Важливу роль комунікації відіграють і в маркетингу. Досить часто, саме ефективністю комунікацій визначається якість і реалізація певних маркетингових рішень підприємства, таких як вихід на нові ринки, підвищення лояльності споживачів чи збільшення продажів певного продукту. Без дієвих комунікацій неможливо забезпечити безперебійне функціонування, а тим більше постійний розвиток організації, і тільки ті компанії, які проводять ефективну комунікаційну політику, можуть надіятися на успіх у майбутньому [7].

Аналіз вітчизняних і закордонних джерел свідчить по те, що проблема маркетингових комунікацій на сьогодні до кінця не розроблена не тільки в Україні, але й у розвинутих в економічному відношенні країнах. Практично всі компанії розглядають маркетингові комунікаційні елементи як самостійні види діяльності, які практично не взаємодіють між собою і не поєднані в єдину систему. Саме тому, в даних умовах виникає необхідність розробки системи маркетингових 
комунікацій (СМК), що відповідають сучасним тенденціям ринку і дозволяють підприємствам бути в достатній мірі конкурентоспроможними.

На даний час існує досить багато визначень терміну «комунікація» (від латинського - повідомлення, передача). В соціології і філософії під комунікацією розуміють обмін інформацією за допомогою символів і образів, а в психології поняття «комунікація» часто ототожнюється з поняттям «спілкування». Не дивлячись на це, практично всі визначення описують маркетингові комунікації як процес взаємодії.

Що стосується комунікацій в маркетингу, то позиції різних дослідників стосовно поняття «маркетингові комунікації» суттєво відрізняються. Це приводить до відсутності систематизованої інформації по даному питанню, яке має велику теоретичну і практичну значимість (табл. 1).

Таблиця 1

Трактування науковцями і спеціалістами в сфері маркетингу поняття «маркетингові комунікації»

\begin{tabular}{|c|c|}
\hline Науковці & Трактування \\
\hline $\begin{array}{l}\text { Дж. Барнетт, } \\
\text { С. Моріарті }\end{array}$ & $\begin{array}{l}\text { Маркетингові комунікації представляють со- } \\
\text { бою процес передачі інформації про товар ці- } \\
\text { льовій аудиторії [2] }\end{array}$ \\
\hline $\begin{array}{l}\text { Ф. Котлер, } \\
\text { К.Л. Келлер }\end{array}$ & $\begin{array}{l}\text { Засоби, за допомогою яких фірми намагаються } \\
\text { інформувати, переконувати і нагадувати спо- } \\
\text { живачам про свої товари і торгові марки [3] }\end{array}$ \\
\hline Ж.Ж. Ламбен & $\begin{array}{l}\text { Сукупність сигналів, що виходять з фірми на } \\
\text { адресу різних аудиторій, в тому числі клієнтів, } \\
\text { збутовиків, постачальників, акціонерів, органів } \\
\text { управління, а також власного персоналу [5] }\end{array}$ \\
\hline $\begin{array}{l}\text { С.І. Стефанов, } \\
\text { Т.А. Беркутова }\end{array}$ & $\begin{array}{l}\text { Маркетингові комунікації ототожнюють з таким } \\
\text { елементом комплексу маркетингу, як просу- } \\
\text { вання [1] }\end{array}$ \\
\hline
\end{tabular}

Приймаючи до уваги вищесказане, під маркетинговими комунікаціями слід розуміти процес обміну інформацією, за допомогою якого ідея про товар, послугу, бренд чи організацію доноситься по певному каналу до цільової аудиторії з метою впливу на ії відношення чи поведінку.

У класифікації «4Р» (Товар, Ціна, Місце і Просування), запропонованою Д. Маккарті, в останній групі, що представляє собою маркетингові комунікації, виділяють чотири підгрупи, і тільки три з них охоплюють інструменти, націлені на привернення уваги потенційного партнера до здійснення угоди з можливим товаром чи послугою, а 
Серія «Економічні науки»

Випуск 4(84) 2018 р.

також вплив на його почуття і на те, чому він надає перевагу. Ці три підгрупи - реклама, особисті продажі і пропаганда. Традиційно інструменти маркетингових комунікацій визначають так:

- реклама - оплачуване виробником опосередковане представлення і просування його ідей, товарів чи послуг. Реклама це найбільш видима складова комунікаційного комплексу, яка представляє і просуває продукт чи послугу через ЗМl;

- особисті продажі - усне представлення товару в процесі спілкування з одним чи кількома потенційними клієнтами з ціллю здійснення певної угоди;

- пропаганда - опосередковане стимулювання попиту на товар чи послугу, шляхом безкоштовного розповсюдження комерційної важливої інформації в засобах масової інформації, або створення сприятливого відношення до нього за допомогою шоу-бізнесу;

3 розвитком маркетингу відносин, підвищенням рівня конкуренції на цільових ринках за потенційних споживачів все більш актуальним стає використання інтегрованих маркетингових комунікацій (IMK). ІМК можна розглядати, як стратегічний підхід щодо управління всіма аспектами комунікацій, важливими для організації і покращення бренду, репутації і прибутковості компанії. Інтегровані маркетингові комунікації використовують сучасні тенденції і роблять особливий акцент на стратегічному маркетингу з метою отримання конкурентних переваг.

Інтегровані маркетингові комунікації підрозділяють на чотири типи повідомлень, про які організація повинна знати, щоб контролювати і впливати на них: заплановані, ймовірні, підтримуючі, незаплановані.

Процес управління IMК передбачає наступні напрямки:

- узгодження комунікації маркетингу з корпоративними цілями;

- узгодження стратегій маркетингових комунікацій з функціональною діяльністю корпоративних блоків (інтеграція по горизонталі);

- інтеграція в рамках маркетингового набору, тобто з урахуванням товарів, цін, розподілу, просування та PR.

Вирішальне значення має бренд компанії, що інтегрує в себе одночасно повідомлення і корпоративний метод привернення уваги цільових аудиторій споживачів; фінансову інтеграцію; інтеграцію позиціонування, яка передбачає використання найновіших інформаційних технологій.

У сучасній економічній літературі діє й інша класифікація ІМК: below the line (BTL), above the line (ATL) - нижче лінії/над лінією; прямого маркетингу; зв'язків із громадськістю, а також технології щодо побудови міжособистісних відносин з необхідним персоналом.

При цьому варто зазначити, що існують певні протиріччя в на- 
борі інструментів для вищеперерахованих понять. «Над лінією» (above the line) знаходиться пряма реклама, що розповсюджується через ЗMI, а також засоби зовнішньої реклами та інформації. Рекламні матеріали працюють на інформування, впізнаваність, нагадування, формування іміджу. Проте комунікаційний канал з потенційним споживачем характеризується опосередкованістю і відсутністю зв'язку. «Під лінією» (below the line) працюють більш складні механізми - стимулювання продажів (sales promotion), стимулювання споживачів (consumer promotion), стимулювання торгівлі (trade promotion).

У табл. 2 наведені сильні і слабкі сторони основних інструментів інтегрованих маркетингових комунікацій.

Таблиця 2

Переваги і недоліки основних інструментів інтегрованих

маркетингових комунікацій

\begin{tabular}{|c|c|c|}
\hline Інструмент & Переваги & Недоліки \\
\hline Реклама, PR & $\begin{array}{l}\text { Найбільш масовий вид кому- } \\
\text { нікацій. Може забезпечити } \\
\text { комплексний вплив на цільову } \\
\text { аудиторію }\end{array}$ & $\begin{array}{l}\text { Нерідко } є \\
\text { нав'язливою. Вима- } \\
\text { гає великих затрат }\end{array}$ \\
\hline $\begin{array}{l}\text { Прямий мар- } \\
\text { кетинг, стиму- } \\
\text { лювання, збут }\end{array}$ & $\begin{array}{l}\text { Допомагає виникненню мит- } \\
\text { тєвої реакції за рахунок ство- } \\
\text { рення додаткових стимулів і } \\
\text { реальної додаткової цінності. } \\
\text { Збільшує ймовірність повтор- } \\
\text { них покупок. Стимулює підт- } \\
\text { римку посередників }\end{array}$ & $\begin{array}{l}\text { Може породити очі- } \\
\text { кування зниження } \\
\text { цін, підірвати імідж і } \\
\text { довгострокову при- } \\
\text { хильність спожива- } \\
\text { чів }\end{array}$ \\
\hline $\begin{array}{l}\text { Зв'язки з гро- } \\
\text { мадськістю }\end{array}$ & $\begin{array}{l}\text { Може підвищити репутацію } \\
\text { фірми. Допомагає розмістити } \\
\text { маркетингові звернення в та- } \\
\text { ких ЗМІ, які несуть фірмі виго- } \\
\text { ду за рахунок своєї високої } \\
\text { репутації і уваги до них зі сто- } \\
\text { рони читачів і глядачів. За- } \\
\text { безпечують взаєморозуміння і } \\
\text { контакти з різними учасника- } \\
\text { ми маркетингового процесу, } \\
\text { що є ключовою умовою здійс- } \\
\text { нення ефективної програми } \\
\text { ІМК }\end{array}$ & $\begin{array}{l}\text { Ïх ефективність } \\
\text { важко піддається } \\
\text { оцінці. Як правило, } \\
\text { не можуть безпосе- } \\
\text { редньо вплинути на } \\
\text { збільшення прода- } \\
\text { жів }\end{array}$ \\
\hline
\end{tabular}


продовження табл. 2

\begin{tabular}{|c|c|c|}
\hline $\begin{array}{l}\text { Директ- } \\
\text { маркетинг }\end{array}$ & $\begin{array}{l}\text { Може мати високу націленість. } \\
\text { Є хорошим способом досяг- } \\
\text { нення обмежених або нішових } \\
\text { аудиторій; економічний при } \\
\text { роботі з невеликими аудиторі- } \\
\text { ями. Може забезпечити кон- } \\
\text { такт з клієнтом «один на } \\
\text { один», а також зворотній } \\
\text { зв'язок із клієнтом }\end{array}$ & $\begin{array}{l}\text { Ефективність зале- } \\
\text { жить від точності } \\
\text { формування бази } \\
\text { даних. Нерідко за- } \\
\text { лишається непомі- } \\
\text { ченим через інфор- } \\
\text { маційне переванта- } \\
\text { ження клієнтів. Ви- } \\
\text { магає великих за- } \\
\text { трат при роботі з } \\
\text { великими аудиторі- } \\
\text { ями. }\end{array}$ \\
\hline $\begin{array}{l}\text { Особисті про- } \\
\text { дажі, упаков- } \\
\text { ка, символіка, } \\
\text { фірмові блан- } \\
\text { ки, спонсорс- } \\
\text { тво }\end{array}$ & $\begin{array}{l}\text { Про просуванні товару є най- } \\
\text { більш персоналізованим ін- } \\
\text { струментом. Постачає най- } \\
\text { більш інформативні і переко- } \\
\text { нуючі звернення }\end{array}$ & $\begin{array}{l}€ \text { найбільш дорогим } \\
\text { із всіх видів марке- } \\
\text { тингових комуніка- } \\
\text { цій. Може визвати } \\
\text { роздратування клі- } \\
\text { єнта, якщо він не } \\
\text { зацікавиться зроб- } \\
\text { леною пропозицією. }\end{array}$ \\
\hline
\end{tabular}

Враховуючи, що суб'єкти господарювання в Україні все більше відчувають на собі вплив факторів глобалізації соціальноекономічних процесів, зростання конкуренції на відповідних сегментах ринку, обмеженості ресурсів, зміни вимог споживачів тощо, саме тому в останні десятиліття вони почали брати на озброєння та активно використовувати сучасні концепції маркетингу: маркетинг відносин, управління взаємовідносинами зі споживачами (CRM), маркетинг 3.0 - «від продуктів до споживачів і далі - до людської душі». Особливо цікавим, і відносно новим, $є$ саме маркетинг 3.0, який передбачає перехід від орієнтації на споживача до орієнтації на людину (особистість), і коли гонитва за прибутком поєднується з корпоративною відповідальністю. В межах цих концепцій увага концентрується на налагодженні тривалих взаємовідносин не тільки зі споживачами, але й з іншими діловими партнерами і контактними аудиторіями (табл. 3). 
Порівняння трьох варіантів маркетингу

\begin{tabular}{|c|c|c|c|}
\hline ב Характеристика & $\begin{array}{c}\text { Маркетинг } 1.0 \\
\text { Орієнтація на } \\
\text { продукт }\end{array}$ & $\begin{array}{c}\text { Маркетинг } 2.0 \\
\text { Орієнтація на } \\
\text { споживача }\end{array}$ & $\begin{array}{c}\text { Маркетинг } 3.0 \\
\text { Орієнтація на } \\
\text { цінності }\end{array}$ \\
\hline Ціль & $\begin{array}{l}\text { Продавати } \\
\text { продукти }\end{array}$ & $\begin{array}{l}\text { Задовольняти } \\
\text { запити і утриму- } \\
\text { вати споживачів }\end{array}$ & $\begin{array}{l}\text { Зробити світ } \\
\text { кращим }\end{array}$ \\
\hline Рушійна сила & $\begin{array}{l}\text { Промислова } \\
\text { революція }\end{array}$ & $\begin{array}{l}\text { Інформаційні те- } \\
\text { хнології }\end{array}$ & $\begin{array}{l}\text { Технології но- } \\
\text { вої хвилі }\end{array}$ \\
\hline $\begin{array}{l}\text { Як компанії роз- } \\
\text { глядають ринок }\end{array}$ & $\begin{array}{l}\text { Масові спожи- } \\
\text { вачі з фізіоло- } \\
\text { гічними потре- } \\
\text { бами }\end{array}$ & $\begin{array}{l}\text { Більше поінфо- } \\
\text { рмовані спожи- } \\
\text { вачі зі своїми } \\
\text { думками і емо- } \\
\text { ціями }\end{array}$ & $\begin{array}{l}\text { Повноцінні } \\
\text { розумні люд- } \\
\text { ські особисто- } \\
\text { сті з емоціями } \\
\text { і душею }\end{array}$ \\
\hline $\begin{array}{l}\text { Ключова марке- } \\
\text { тингова концеп- } \\
\text { ція }\end{array}$ & $\begin{array}{l}\text { Розробка това- } \\
\text { рів }\end{array}$ & Диференціація & Цінності \\
\hline $\begin{array}{l}\text { Принципи мар- } \\
\text { кетингу }\end{array}$ & $\begin{array}{l}\text { Акцент на ха- } \\
\text { рактеристиках } \\
\text { продукту } \\
\end{array}$ & $\begin{array}{l}\text { Позиціонування } \\
\text { компанії і про- } \\
\text { дукту }\end{array}$ & $\begin{array}{l}\text { Місія, бачення } \\
\text { і цінності ком- } \\
\text { панії }\end{array}$ \\
\hline $\begin{array}{l}\text { Споживча вар- } \\
\text { тість }\end{array}$ & Функціональна & $\begin{array}{l}\text { Функціональна і } \\
\text { емоційна }\end{array}$ & $\begin{array}{l}\text { Функціональ- } \\
\text { на, емоційна і } \\
\text { духовна }\end{array}$ \\
\hline $\begin{array}{l}\text { Взаємодія зі } \\
\text { споживачем }\end{array}$ & $\begin{array}{l}\text { «Один з бага- } \\
\text { тьма» }\end{array}$ & «Один на один» & $\begin{array}{l}\text { «Співпраця } \\
\text { багатьох з ба- } \\
\text { гатьма» }\end{array}$ \\
\hline
\end{tabular}

* Джерело: [4]

Продумана маркетингова стратегія, зорієнтована на кінцевого споживача, покликана визначити напрямки діяльності щодо підвищення конкурентоспроможності та пошуку конкурентних переваг на ринку, забезпечити налагодження ефективних внутрішніх і зовнішніх комунікацій, сформувати і закріпити позитивний імідж суб'єкта господарювання.

Таким чином, можна зробити висновок, що ІМК представляють собою систему активних методик розвитку бізнесу, яка об'єднує знання з різних сфер, зокрема таких, як: реклама, менеджмент, маркетинг, соціологія, психологія, економіка, інтегруючи не тільки методи і канали подачі інформації, але й персоніфікуючи інформаційні потоки у зовнішньому середовищі організації чи підприємства, до- 
зволяє добиватися сенергічного ефекту інформаційної взаємодії фірми та основних її стейкхолдерів, дії, поведінка чи рішення яких можуть вплинути на успіх системи.

1. Беркутова, Т. А. Маркетингові коммуникації. Ростов н/Д : Фенікс, 2008. 254 с. 2. Бернет Дж., Мориарти С. Маркетинговые коммуникации: интегрированный подход. 3. Котлер Ф., Келлер К. Л. Маркетинг менеджмент. 15-е изд. Питер, 2018. 848 с. 4. Котлер Ф. Маркетинг 3.0. URL: https://wmhelp.net/lib/b/book/1009110634/6 (дата звернення: 10.05. 2019). 5. Ламбен Ж-Ж. Стратегічний маркетинг. Європейська перспектива / пер. с французского. СПб, 2016. 589 с. 6. Сміт П., Бєрри К., Пулфорд А. Комунікації стратегічного маркетингу. Москва, 2011. 415 с. 7. Худоногов А. В. Сучасна система маркетингових комунікацій і структурний взаємозв'язок ії компонентів URL: https://cyberleninka.ru/article/v/sovremennaya-sistema-marketingovyhkommunikatsiy-i-strukturnaya-vzaimosvyaz-ee-elementov (дата звернення: 10.05. 2019).

\section{REFERENCES:}

1. Berkutova, T. A. Marketynhovi kommunykatsii. Rostov n/D : Feniks, 2008. 254 s. 2. Bernet Dzh., Moriarti S. Marketinhovye kommunikatsii: intehrirovannyi podkhod. 3. Kotler F., Keller K. L. Marketinh menedzhment. 15-e izd. Piter, 2018. 848 s. 4. Kotler F. Marketinh 3.0. URL: https://wmhelp.net/lib/b/book/1009110634/6 (data zvernennia: 10.05. 2019). 5. Lamben Zh-Zh. Stratehichnyi marketynh. Yevropeiska perspektyva / per. $s$ frantsuzskoho. SPb, 2016. 589 s. 6. Smit P., Bierry K., Pulford A. Komunikatsii stratehichnoho marketynhu. Moskva, 2011. 415 s. 7. Khudonohov A. V. Suchasna systema marketynhovykh komunikatsii i strukturnyi vzaiemozviazok yii komponentiv URL: https://cyberleninka.ru/article/v/sovremennayasistema-marketingovyh-kommunikatsiy-i-strukturnaya-vzaimosvyaz-eeelementov (data zvernennia: 10.05. 2019).

Рецензент: д.е.н., проф. Мальчик М. В. (НУВГП)

Koval S. I., Senior Lecturer (National University of Water and Environmental Engineering, Rivne)

\section{PECULIARITIES OF FORMATION OF INTEGRATED MARKETING COMMUNICATIONS IN CONDITIONS OF COMPETITIVE ENVIRONMENT}

In the context of the globalization of the economy, the expansion of the competitive environment is increasingly the role of information, it becomes one of the most important elements used to effectively manage the activities of business entities. The increasing pace of informatization in society is providing consumers with an increasing 
amount of information. Iï Transmission from object to object is done through a specific form of communication - communication. Integrated marketing communications play a key role in addressing these challenges. However, the unstable economic situation in the country, difficulties in financing the relevant measures led to a reduction in marketing budgets. Therefore, there is a growing need to find cost-effective and, at the same time, effective ways of communicating with consumers. Only those companies that are well aware and understand their customers (customers) and competitors, conduct effective communication policies, will succeed in the target market.

Keywords: marketing communications, integrated communications, consumers, information, sharing.

Коваль С. И., ст. преподаватель (Национальный университет водного хозяйства и природопользования, г. Ровно)

ОСОБЕННОСТИ ФОРМИРОВАНИЯ ИНТЕГРИРОВАННЫХ МАРКЕТИНГОВЫХ КОММУНИКАЦИЙ В УСЛОВИЯХ КОНКУРЕНТНОЙ СРЕДЫ

В условиях глобализации экономики, расширения конкурентной среды все больше возрастает роль информации, она становится одним из самых значимых элементов, используемых для эффективного управления деятельностью субъектов хозяйствования. Растущие темпы информатизации общества предоставляют потребителям все большие объемы информации. Ее передача от объекта к объекту происходит с помощью специфической формы общения коммуникаций. В решении этих задач основное место принадлежит интегрированным маркетинговым коммуникациям. Однако нестабильная экономическая ситуация в стране, трудности с финансированием соответствующих мероприятий привели к сокращению маркетинговых бюджетов. Поэтому возрастает необходимость поиска экономических и одновременно эффективных способов коммуникации с потребителями. Только те компании, которые хорошо знают и понимают своих потребителей (клиентов) и конкурентов, проводят эффективную коммуникационную политику, будут иметь успех на целевом рынке.

Ключевые слова: маркетинговые коммуникации, интегрированные коммуникации, потребители, информация, обмен. 